\title{
'News From home' De Chantal AKERMan: El DOCUMENTAL AUTOBIOGRÁFICO EN EL CONTEXTO DEL DOCUMENTAL CONTEMPORÁNEO
}

\author{
'News from Home' by Chantal Akerman: the \\ autobiographical documen-tary in the context of \\ contemporary documentary
}

\author{
Ddo. Pablo MORENO RUÍZ \\ Estudiante de Máster en Patrimonio Audiovisual \\ Universidad Complutense de Madrid. España \\ E-mail: pablmo01@ucm.es \\ (iD) http://orcid.org/0000-0002-8264-7240 \\ Dra. Mar MARCOS MOLANO \\ Profesora Titular \\ Universidad Complutense de Madrid. España \\ E-mail:mmmarcos@ucm.es \\ (D) http://orcid.org/0000-0002-8738-6244
}

Fecha de recepción del artículo: 31/03/2019

Fecha de aceptación definitiva: 21/04/2019

\section{RESUMEN}

Esta investigación centra su interés en el documental 'News from Home' (1977) de Chantal Akerman, como ejemplo de documental autobiográfico hecho por mujeres. El relato de la cineasta transita los cimientos de la relación materno filial para provocar la reflexión sobre la relación entre mujeres, el pulso generacional, lo cotidiano o lo extraordinario de sus vidas, el vacío emocional. Partiendo de las tipologías de inscripción autobiográfica (autorretrato, cine familiar, cine "amateur", diario de viaje, diario filmado, cartas filmadas) el análisis de esta pieza nos permitirá además identificar muchas de las características del documental autobiográfico contemporáneo, como la renuncia a la objetividad, la ruptura de las fronteras entre la ficción y la no ficción, o el uso de una gramática audiovisual particular que actúe como catalizador de la expresión de dos universos: el mundo íntimo del «yo» de Akerman y su representación simbólica en el relato documental contemporáneo.

Palabras clave: cine documental; documental autobiográfico; documental íntimo; autorepresentación; Chantal Akerman.

\section{ABSTRACT}

This research focuses on Chantal Akerman's documentary 'News from Home' (1977), as an example of an autobio-graphical documentary made by women. The filmmaker's story 
goes through the foundations of the filial maternal relationship to provoke a reflection on the relationship between women, the generational pulse, the day-to-day routine or the extraordinary nature of their lives, the emotional void. Starting from the typologies of autobiograph-ical inscription (self-portrait, family cinema, amateur cinema, travel diary, filmed diary, filmed letters) the analysis of this piece will also allow us to identify many of the characteristics of contemporary autobiographical documentary, such as the renunciation of objectivity, the breaking of the boundaries between fiction and non-fiction, or the use of a particular audiovisual grammar that acts as a catalyst for the expression of two universes: Akerman's intimate world and its symbolic representation in contemporary documentary narrative.

Key words: documentary film; autobiographical documentary; intimate documentary; self-representation; Chantal Akerman.

\section{INTRODUCCIÓN: CINE DOCUMENTAL}

El cine, desde sus orígenes, ha poseído una clara vocación referencial, en tanto que su relación con su entorno se construye sobre la inmediatez y la captación directa de lo real. Con esta idea nacieron muchas de las vistas tomadas por empresas de cine (Pathé) en los primeros años del medio, o las pequeñas piezas de los hermanos Lumière que centraban sus tomas en la captación de lo cotidiano. No en vano, teóricos como Efrén Cuevas (2008, p. 101), encuentran en obras como 'Repas du bébé' (Louis Lumière, 1895) un antecedente del posterior cine doméstico. Paralelamente, el cine encuentra en la ciencia un importante referente para sustentar sus avances científicos como imagen de registro de lo real que puede incluso sustituir al referente. Tal es el caso de los primeros estudios sobre patologías del movimiento realizadas por Muybridge o de operaciones quirúrgicas grabadas en vivo. Visto así, el cine anuncia desde sus orígenes su capacidad de servir como instrumento de documentación e investigación y se establece una clara vinculación del cine documental con los llamados discursos de sobriedad (científico, político, económico, social y educativo). Esto supuso que al documental se le auguró una falta de personajes, situaciones y mundos anclados en la ficción, más bien sus propuestas conllevaban una confrontación directa con la realidad social: "el documental, como otros discursos de lo real, conservan una responsabilidad residual de describir e interpretar el mundo de la experiencia colectiva, una responsabilidad que en modo alguno es una cuestión menor» Nichols (1997, p. 40).

Sin embargo, es importante subrayar que en el documental existe una interpretación del mundo, no únicamente una descripción. Que el documental implique posicionarse ante una realidad, con lo que eso conlleva en cuanto a contingencia, no supone necesariamente la inexistencia de una intervención por parte del cineasta. Se comprueba en ello cierta paradoja, ya que «lo que el documentalista no puede controlar plenamente es su tema básico: la historia» (Nichols, 1997, p. 43); ello no es óbice para que lo que se presente ante el espectador sea una construcción, una perspectiva que el cineasta lanza, al contraponer y enfrentar varios puntos de vista, sobre unos hechos para entenderlos y explicarlos en su sentido más profundo (motivos, orígenes, consecuencias, etc.) No se limita a describir y reproducir una realidad, con esa aspiración a lo objetivo tan ligado a lo documental, sino a ahondar en ella a través de una serie de recursos expresivos pertenecientes al medio; es decir, y como consecuencia de esto, con una clara inclinación a un tratamiento creativo de dicha realidad. 
Pero ¿qué ocurre cuando la subjetividad inunda estas prácticas como lo hace en el cine documental de lo íntimo y del yo? Nichols ve en la subjetividad la posibilidad de poner en peligro la credibilidad del relato al traspasar las fronteras entre la no ficción, o donde la mayor presencia del sujeto que construye el documental supone un alejamiento de aquello que trata de representar: «la afirmación de que esto es así, con su tácito ¿verdad? -una solicitud de consentimiento que induce a creer-, hace de la objetividad y de lo denotativo, un aliado natural de la retórica documental» (Nichols, 1997, p. 61). Sin embargo, desde hace unas décadas, lo subjetivo se ha establecido como una tendencia común y bastante generalizada. ¿Qué supone para la no ficción el alejamiento de esos discursos de sobriedad enunciados por Nichols?

\section{HIPÓTESIS Y OBJETIVOS}

La presente investigación realiza un estudio de la auto representación de Chantal Akerman en la obra documental autobiográfica, esto es, la forma en la que la cineasta construye esa realidad del "yo» mediante determinadas claves enunciativas y estructuras narrativas. En consecuencia, al profundizar en cómo se manifiesta el punto de vista de la autora a la hora de abordar dicha realidad, se investigará si esta representación del "yo» interfiere en la pérdida del valor de la pieza como documento de lo real.

Para ello nos hemos planteado los siguientes objetivos: contextualizar y conceptualizar el documental autobiográfico con el fin de encontrar sus señas de identidad en el conjunto del documental contemporáneo; realizar un análisis fílmico que permita establecer las estrategias y mecanismos enunciativos que emplea la cineasta Chantal Akerman en la construcción de su obra; encontrar el origen del documental de lo íntimo, su tipología y necesidad en el contexto del cine de no ficción contemporáneo.

\section{MéTOdo De ANÁLISIS}

El método empleado se sustenta en el análisis fílmico desde el punto de vista de la estética cinematográfica, poniendo de relieve los elementos que, entendemos, forman parte esencial del corpus narrativo del documental íntimo o documental del "yo».

Análisis de personajes. Se adoptará el término personaje-autor para determinar al personaje central, esto es, el propio autor de la obra. Partiendo de ello, discernir si en el filme sólo existe dicho personaje, o por el contrario éste se relaciona con otros. Estudiar qué clase de personas, si son familiares u otros de su entorno. Analizar si el dispositivo se centra únicamente en sí mismo u otros elementos y recursos de su entorno, cercano o no, para construir y sumergirse en su propia identidad. En cuanto al personaje-autor, determinar el tiempo que aparece en el documental: si es total, parcial o está indirectamente inducido en la obra mediante otros elementos, esto es, si está presente físicamente o no. Se distingue un papel de doble rol en el que el director porta la cámara y al mismo tiempo es auto representado (juego con el espejo), u otro en el que no se dé el caso. Igualmente, si no existe una presencia física del autor, se debe investigar de qué otras maneras su presencia es sugerida al espectador.

Análisis de contenido. Es necesario valorar de qué se está hablando en el documental, qué temática se está dando y si ésta es ajena o no a su persona. Si se está centrando más en temas que en principio no tienen que ver directamente con él, pero que igualmente están dando una visión indirecta de sí mismo en lo que respecta a 
su relación con el entorno que le rodea, o si, por el contrario, opta por abordarse directamente en un sentido más íntimo. Si se da el primer caso analizar de qué forma y qué recursos emplea para auto referenciarse, pudiendo ser, por ejemplo, mediante el ensayo o la reflexión filosófica sobre el propio dispositivo cinematográfico o el mismo hecho de tratar y hablar sobre la forma personal que tiene cada uno de realizar un documental. En este sentido, la manera en la que se identifica cada autor como personaje es vital. Es decir, si lo hace en una faceta más personal e íntima (en el entorno familiar, por ejemplo), o prefiere abordar de sí mismo su lado profesional, como creador de imágenes y cineasta.

Análisis de los espacios. Los lugares por los que discurre el documental puedan dar una idea clave, en función de si trabaja interiores o exteriores: si se da la primera opción, seguramente se estará ante una faceta más de arqueólogo, de búsqueda de lo personal e íntimo en el hogar, de un pasado más o menos remoto; en el segundo caso, como es el de diario de viaje, se especulará más sobre la idea del explorador en el que el autor interroga al mundo y a sus gentes, e indirectamente a sí mismo.

Análisis del sonido. Empleo o no de voz en off: mientras que utilizarla fomenta la idea de ensayo e introspección del autor, su renuncia puede significar un mayor interés por la ambigüedad y la sugerencia de las imágenes. Ser capaz de definir, entonces, si hay un mayor peso de la imagen o el sonido. El empleo de banda sonora o el uso únicamente de elementos sonoros diegéticos y ambientales, es, igualmente, elemento determinante para completar el sentido documental.

Tipo de fuentes y materiales. Esta faceta dicotómica de arqueólogo-explorador se puede derivar también al estudiar el material sobre el que el director va a trabajar. Es decir, puede tratarse de material de archivo (familiar o no), movido por el propósito de la apropiación y la reelaboración de material ajeno para preguntarse acerca del pasado, o puede optarse por la posibilidad de grabar su propio material sumergido en la necesidad de captar lo instantáneo y azaroso del entorno.

\section{Marco CONCEPTUAL: AUTOBIOGRAFÍA}

Las propuestas de producción íntima y personal tienen su génesis normalmente en una tradición literaria que navega entre lo que Leujene (1994, p. 51) refiere como autobiográfico y va del autorretrato, al poema autobiográfico, la novela autobiográfica, los diarios personales, las memorias y el ensayo. Refiriéndose al autorretrato como «el relato retrospectivo en prosa que una persona real hace de su propia existencia, poniendo énfasis en su vida individual y, en particular, en la historia de su personalidad» (Leujene, 1994, p. 50), esta definición parece responder a una tentativa por acotar el objeto de estudio, que ha sido puesto en duda por otros teóricos al ser excluyente; entre ellos Paul John Eakin (1994, p. 11), quien opina que dicha definición "manifiesta sin embargo tres aspectos tendenciosos de Lejeune como estudioso de la autobiografía: su orientación hacia la prosa, su preocupación por los aspectos temporales del relato y su atracción hacia la psicología y el psicoanálisis». Se entiende, por tanto, que existe una heterogeneidad y ambigüedad en torno al concepto, que abarcaría otras manifestaciones que no necesariamente entran en el relato y en lo cronológico como inicialmente afirma esa definición. Es decir, lo autobiográfico entraría en una concepción mucho más elástica en la que un autor se ha propuesta la intención de exponer unos pensamientos o sentimientos. 
La confusión sobre el término se inicia incluso en la tentativa de incluirlo como género. Lejeune (1994) se posiciona a favor de ello, y en su camino para distinguir lo autobiográfico de la novela autobiográfica, es decir, lo fáctico de la ficción, elabora su teoría sobre el pacto, posicionándose en el punto de vista del lector. Éste era inicialmente entendido como un compromiso entre el autor y el receptor donde éste último entiende que se está afrontando la propia vida desde la sinceridad y honestidad. Curiosamente esta idea se aproxima a la mencionada anteriormente sobre el compromiso y responsabilidad del documentalista en el cine, por el que se crea un acuerdo tácito entre director y espectador, basado en unos códigos de veracidad previos, que da la idea de visionar una representación fidedigna de una realidad (sea la del "yo» o cualquiera).

Posteriormente Lejeune pule esta idea afirmando que para que se dé lo autobiográfico tienen que coincidir la identidad del autor, narrador y del personaje. «El pacto autobiográfico es la afirmación en el texto de esta identidad, y nos envía en última instancia al nombre del autor sobre la portada” (Leujene, 1994, p. 64). Esta articulación se construye, por tanto, entorno al empleo del nombre personal, más que en el uso del «yo» o de la primera persona. Es decir, «lo que define la autobiografía para quien la lee es ante todo un contrato de identidad que es sellado por el nombre propio» (Leujene, 1994, p. 72).

\subsection{Cine documental íntimo}

Cuando Elizabeth W. Bruss (1980) consideró inviable la vinculación entre lo autobiográfico y el cine, suscitó la primera controversia. Más allá de entrar en ese debate y puesta en duda, que ya tuvo su contestación teórica por parte de otros autores, entre ellos el propio Lejeune, lo que es incuestionable es que esa tendencia se ha dado y existe, incluso de una forma más generalizada y sistemática en las últimas décadas. Se puede hablar de un interés por parte de una serie de cineastas por explorar su intimidad o el yo mediante unos recursos expresivos de índole cinematográfica para generar una idea de auto representación: se trata de un proceso de búsqueda que puede apoyarse en lo performativo o en la apropiación (de material doméstico, por ejemplo) con la pretensión de construir una identidad, la propia. Una construcción fílmica en la que, en contraposición a lo que manifiesta Nichols sobre el objetivo de saciar el conocimiento del espectador propio del documental, nos enfrentaríamos al documental que repara en el desarrollo del autoconocimiento para enfrentarlo sin filtro al espectador.

Las primeras propuestas tuvieron lugar dentro de las vanguardias cinematográficas americanas de mediados de siglo, siendo la más relevante los diarios filmados de Jonas Mekas. Por ello no debe extrañar que las primeras manifestaciones de lo íntimo "se mantuvieron siempre en los extramuros de los sistemas de producción industriales, acuñándose en espacios cinematográficos independientes y experimentales, privilegiando, en consecuencia, formatos de cine "amateur» como el 16 y el $8 \mathrm{~mm}$ en celuloide, y luego el vídeo doméstico y digital» (Lagos Labbé, 2012, p. 14). Esto supone que la mayoría de los filmes se empaparan de esa estética «amateur» habitual en el cine doméstico, por la que los cineastas de vanguardia «mostraron gran interés como cualidad para experimentar formalmente la gramática audiovisual y emanciparse del cine industrial» (Cuevas, 2005, p. 235). Con el crecimiento en el número de propuestas de 
las últimas décadas del siglo XX, gracias en parte a la proliferación de medios videográficos y digitales, pasan a ocupar «espacios de exhibición y distribución de cine documental tales como festivales internacionales (no solo aquellos especializados en el género), donde estas películas suelen ser ampliamente premiadas y a menudo logran - sin siquiera perseguir la masividad- repletar las funciones y cosechar una inaudita atención crítica» (Lagos Labbé, 2012, p. 14); por lo que dejan de ser algo anecdótico o a estar únicamente presentes como elemento secundario en películas de ficción, para convertirse en una de las tendencias del documental contemporáneo, como rasgo principal sobre el que se vertebra el filme.

Pero si algo ha preocupado a los teóricos en esta materia, es la confusión terminológica que se deriva de ella. Puesto que se habla de una tendencia vinculada a la vanguardia y al documental de los últimos años (en los que predomina la experimentación, la subjetividad y la creatividad), existe gran dificultad para encorsetar desde un punto de vista teórico las diferentes obras. Y esto es así principalmente porque la mayoría de las veces se exceden las fronteras entre géneros, precisamente en un cine que pretende ser libre y personal. En este sentido, Jim Lane (2002) intenta aclarar la dificultad terminológica, distinguiendo entre «journal entry autobiography» y el «autobiographical portrait» (familiar o de sí mismo). En el primer caso, Lane incluye los documentales que se basan en un desarrollo cronológico en forma de diario, con la captación de lo que acontece en torno al cineasta, mientras que en el otro se busca una aproximación más directa, muchas veces con el uso de material de archivo (combinando pasado y presente) o entrevistas (a familiares).

En el tratamiento de diario, se habla normalmente de imágenes «registradas a lo largo de períodos prolongados en la vida de un cineasta (varios años o décadas)" (Lagos Labbé, 2012, p. 16). Lo interesante es la doble fase de creación que existe en ellas:

En una primera fase tendríamos los "films diaries", las entradas diarias que el cineasta va grabando sin un plan previo, y que se asimilan en cierto modo al diario escrito, en cuanto que no cuentan con más estructura que su propia secuencialidad cronológica. Se distinguen, sin embargo, del formato escrito, por su dimensión puramente visual [...] y sobre todo por su anclaje en el presente inmediato del acontecimiento, sin la distancia retrospectiva del diario que, aunque sea mínima, ya aporta una reflexión y reconstrucción narrativa sobre lo acontecido. Más tarde esos "films diaries» se convierten en "diary films", en películas con una duración determinada, preparadas para ser exhibidas públicamente. En esta segunda fase, el cineasta tiene que elegir un período temporal y realizar un montaje del material rodado [...] se incorporan nuevas capas expresivas, como intertítulos, músicas y en especial el comentario del auto-narrador (Efrén Cuevas, 2008, p. 107).

Esto último es lo que aporta el carácter retrospectivo que autores como Lejeune asocian a lo autobiográfico. Dando un paso más, podríamos incluir otro tipo de diario, el de viajes, de similares características que el anterior, pero con la diferencia de que en él se suceden unos «desplazamientos cartográficos o espirituales, efectivos o afectivos, en que los cineastas errantes avanzan animados por reencontrar las propias huellas del pasado, y fruto de dicho movimiento interior y exterior, emprender un sendero que explore dentro de sí mismos» (Lagos Labbé, 2012, p. 17).

Por otro lado, conviene diferenciar entre lo autobiográfico y el autorretrato: si lo autobiográfico se entiende como un relato referencial de tipo memorístico (ahondar en la infancia, por ejemplo) que abarca una vivencia más o menos prolongada en el 
tiempo, el autorretrato se caracteriza "por la ausencia de todo relato estructurado" (Bellour, 2009, p. 294). En ello se ve un mayor tratamiento de lo metafórico y a lo poético, no contando lo que se ha hecho, sino quién es esa persona en una concepción más abstracta y atemporal.

No obstante, para evitar esta confusión, y en la que nunca se sabe con seguridad si se está ante una autobiografía o un autorretrato, en estas líneas se hablará de cine documental íntimo o del «yo», donde conviven diferentes tendencias: autobiografía, retrato (familiar o de sí mismo), diario filmado, diario de viajes, ensayo y la carta filmada. Se crea un vínculo entre ellas cuando poseen un interés en común, por desarrollar una búsqueda de lo personal, en la que se gesta un autoconocimiento y una proyección sobre sí mismo, y en el que se materializa una auto representación. Todo ello sin olvidar que ninguna de estas manifestaciones se da de forma pura, sino que se ven contaminadas unas con otras: 'News from Home', por ejemplo, entra dentro de la carta filmada pero igualmente se puede entender como un retrato familiar.

\section{5. 'NEWS FROM HOME' (1977) DE CHANTAL AKERMAN}

La carrera de Chantal Akerman se inicia en 1968 motivada por captar lo cotidiano en su entorno: sin guion, con medios austeros, sin argumentos ni mayor pretensión que atrapar lo personal, entre el documental, el diario íntimo y una inclusiva mirada que entroncar con su entorno. Esta singular mirada da como resultado una trayectoria artística que desafía las convenciones, no solo por su particular uso de la gramática audiovisual sino por el tratamiento de las mujeres, figura central de su obra.

'Jeanne Dielman, 23 quai du Commerce, 1080' (1976) marcó el exitoso arranque de su carrera, para posteriormente moverse entre diferentes géneros: comedia, musical, drama y documental. Fue cercana al mundo del videoarte y de las artes plásticas, con sus propias instalaciones audiovisuales para museos, además de responder al concepto de "cineasta viajante». Atravesó en coche la Unión Europea, pasando por París, Ámsterdam, o Londres, y voló a lugares como Nueva York, Chicago y San Francisco, además de visitar la antigua Europa socialista del Este, o explorar la frontera conflictiva entre Estados Unidos y México (Marías, 2005, p. 9). Estos recorridos marcaron trayectos por los que la mirada de Akerman transita de forma orgánica, reconstruyendo el tiempo narrativo de manera realista, llevando la significación simbólica del plano al límite, gracias la ceremoniosa lentitud de su dispositivo. El resultado son planos larguísimos en su duración, en un ritmo que podríamos denominar de la inmovilidad, como fotografías que atrapan el tiempo congelando nuestra mirada y sosteniéndola en el tempo simbólico del relato. Su propuesta formal se justifica con su propuesta de contenido. Akerman emulsiona el espacio público con el espacio de lo privado y su obra pasea con naturalidad los recodos más banales de la cotidianidad de las mujeres: sus rutinas llenan la atmósfera de cada encuadre que, en su larga temporalidad, retrata el tedio de sus vidas donde no parece pasar nada. Es el vacío en la vida de millones de mujeres.

'News from Home', es un extraordinario documento de la ciudad que Akerman realizó a raíz de su segunda estancia en Nueva York en un momento clave de su historia, guiado por la poética mirada de la cineasta. En él se observan una serie de imágenes de la ciudad de trascendente plasticidad, la mayoría en planos fijos de larga duración, mientras se escucha una voz femenina leer las cartas de la madre de 
la directora -Natalia Akerman- enviadas desde Europa. Se trata de un filme de tipo epistolar. Es, además, un ejemplo claro en el que sonido e imagen dialogan infatigablemente para generar el sentido pleno de la película, tanto en el plano de significado como en el emocional: reproches, celos, amor..., el futuro, la ciudad, el pasado..., frente a las palabras que, poco a poco, se van desvaneciendo.

El concepto clave sobre el que se cimenta el documental es la relación madre-hija, temática que ha recorrido la obra de Akerman en numerosas ocasiones desde la aparición únicamente sonora de su madre en 'Aujourd'hui, dis-moi' (1982) -documental en el que entrevista a tres ancianas judías polacas acerca de sus experiencias en un campo de concentración nazi-, hasta su último filme 'No Home Movie' (2015) -retrato de la muerte de Natalia Akerman-. El interés por su madre nace de una búsqueda de sus orígenes, un ejercicio de autodefinición y comprensión de su identidad judía. Ella pertenecía a la llamada "segunda generación", es decir, era hija de padres que habían sobrevivido al Holocausto. Pero ante la insistencia por discernir ese pasado, su madre siempre había guardado silencio para evitar el dolor del recuerdo. Ello no impidió que Chantal Akerman empleara el medio cinematográfico para abordar la historia del pueblo judío, y así conocer lo que no le habían querido contar sobre su pasado familiar. Es decir, es un camino en el que se entremezclan la historia y lo personal, y en el que la directora no se perfila como un sujeto ajeno a ésta, sino como una parte integrante (Otero, 2005). De esta manera, la pieza entra en el terreno de lo autobiográfico precisamente para indagar en su origen judío y la trascendencia de ese hecho.

En el documental existen, por tanto, dos personajes: la madre Natalia y la hija Chantal, aunque con menciones en las cartas a otros familiares. Es claro que el entorno en el que se desplaza, en este caso, lo autobiográfico es lo familiar. No se sale apenas de ese ambiente íntimo, al menos en el plano sonoro, el de la voz femenina que lee las cartas, en contraste a la omnipresente visualidad de la ciudad de Nueva York. La auto-representación de la directora se aleja de cualquier presencia física, al igual que la de la madre. Es decir, la película se construye en base a la ausencia de ambos personajes, que serán referidos indirectamente a través del elemento conductor del documental: las cartas. Aunque la no presencia física de Natalia Akerman es absoluta, la ausencia de Chantal es aún mayor ya que las cartas que escuchamos han sido escritas por su madre, en ningún caso se trata de las de ella.

El influjo y huella de la cineasta se sublima, sin embargo, a través del punto de vista que atribuye al espectador sobre Nueva York, su mirada sobre la ciudad, fragmentada en largos planos y escasos movimientos de cámara, que cobran su pleno sentido cuando se superponen la lectura y la imagen: la hija que se ha alejado del nicho familiar, de Europa, para pasar una larga e indefinida estancia en Estados Unidos. Esa ausencia, o presencia indirecta si se prefiere, refleja la idea de lo "phantasmatic" que Brenda Longfellow explica como característica común en la obra de la directora: "If there is a recurring phantasmatic core to the work of Chantal Akerman, it lies in the desire to reconstitute the image of the mother, the voice of the mother» (Longfellow, 1989, p. 73).

Los temas que se abordan en el documental son en apariencia insignificantes. Tanto las imágenes que Chantal muestra de Nueva York como las confidencias que Natalia escribe en sus cartas, no sobrepasan lo cotidiano, habitual y ordinario: se dice que cierta persona ha enfermado; que el padre ha encontrado trabajo; que una pareja se ha casado; que otra ha tenido un bebé... Pero sobre todo las cartas transmiten la insistencia de la madre para que su hija vuelva a casa o, por lo menos, saber cuándo 
va a volver; del trabajo de ella en Nueva York..., y todo ello enmarcado en una sucesión de imágenes aleatorias de las calles, del metro, de los transeúntes, de coches, de edificios, del asfalto: todo aparentemente ordinario.

Pero lo aparentemente cotidiano, conquista su legítimo valor cuando ambos mundos, el de las cartas y el de las imágenes, se suman el uno al otro accediendo al plano de la significación plena. Esta fusión, generada exclusivamente por el lenguaje cinematográfico, desafía al observador con la reflexión sobre el hogar, la añoranza -por parte de la madre y tal vez de Chantal-, la evocación y el recuerdo, sobre la ausencia subrayada con la no presencia física de ninguna de las dos mujeres. Esta contraposición entre imagen y sonido es además lo que enfrenta "dos espacios en la película, dos aspectos de la identidad de Akerman que coexisten y constantemente se sobreponen» (Schlenker, 2009, p. 211). En el documental priman las imágenes en exteriores, con alguna en el metro de la ciudad, por lo que se habla de un espacio representado y físico, el de Nueva York; y otro espacio proyectado en la mente del espectador, un espacio imaginario, el de Europa y el hogar. Un juego constante entre un espacio en campo y otro en fuera de campo, el cual sólo se puede evocar mediante las misivas. Y todo ello empleado como recurso para recrear la complejidad de la identidad, tanto del yo presente y actual que dejó atrás el hogar, como el yo del pasado que se niega a desaparecer, pero que sólo puede ser evocado y nunca recuperado.

Por otro lado, el empleo del elemento sonoro es significativo. Se ha descartado cualquier uso de música extradiegética, lo único que se escucha es el ambiente sonoro de Nueva York, en el que se suceden los ruidos de coches principalmente, junto con los pasos de los transeúntes y alguna que otra voz lejana de éstos, aunque en ningún caso se oye lo que dicen. En cualquier caso, lo más significativo es la interacción entre estos sonidos y la voz femenina que lee las cartas. La superposición de imágenes y sonidos inconexos para generar un determinado significado emocional encuentra en esta pieza una extraordinario expresión: constantemente el ruido ambiental, por ejemplo, el de los coches al pasar cerca de la cámara, ensordece el contenido de las cartas, llegando únicamente ciertos fragmentos y obstaculizando otros. Esto consigue una idea de relación orgánica, de dos mundos separados físicamente pero profundamente ligados y conectados emocionalmente. La evocación de la que se habla en relación al espectador, también se siente unida a la directora, como huella de la auto representación. Una ensoñación que se ve interrumpida por el devenir de la ciudad, es decir, una mente que vaga incesantemente dos espacios: son los espacios de lo público y de lo privado que la cineasta representa en ensayada armonía.

En esta línea, la mirada de la directora, su propio punto de vista se muestra lejano en cuanto a lo que ve. La ciudad de Nueva York parece algo ajena a ella, cumpliendo un papel pasivo, un lugar desde el que sólo cabe mirar: la gente sale y entra en campo constantemente la mayoría de las veces sin prestar atención a la cámara, con excepciones fortuitas de personas que se la quedan fijamente mirando, extrañadas algunas veces, con diversión y risa en otros casos. Se ven desde la lejanía, en alguna ocasión como un reflejo sobre las puertas del metro, en otras ocasiones enmarcados por los ventanales de sus lugares de trabajo, o con la cabeza cortada por el encuadre u ocultos por el paso de los vehículos y el metro. Son pequeños fragmentos de una vida diaria, coral y cotidiana cuyo paisaje urbano incesantemente cambia y de los cuales se es testigo desde un punto de vista lejano y externo impuesto por la directora. Como si no estuviera plenamente conectada con esos lugares, y las cartas la arrastraran irremediablemente a Europa. Pero sobre este último, la conexión absoluta tampoco 
se produce: Natalia Akerman no cesa de apremiar a su hija para que le escriba más a menudo y que le responda al contenido de sus cartas, como si por ese lado también hubiera resistencia y distancia con ese mundo. Al final no se tiene la sensación plena de estar en ninguno de los dos espacios, sino que, por el contrario, se estuviera confinado en una especie de limbo.

Y en medio de todo ello, la idea recurrente de transición y de viaje, uno en el que ella misma se ha embarcado y que es remarcado por la presencia absoluta de los vehículos de la ciudad, del metro, de lugares de paso (escaleras), de los pasajes mudables que la cámara capta desde un coche, e incluso, como dibujo final, por la imagen de Nueva York, brumosa y cada vez más distante, desde una barca con la que se cierra la película. Todo funciona como un entramado emocional y melancólico en el que Chantal Akerman constituye un estado anímico, el suyo, en un contexto y tiempo determinado. Un documental, en definitiva, que cimenta todo su discurso sobre la identidad, como un espacio de descubrimiento, autoconocimiento y construcción.

\section{RESULTADOS}

A finales del siglo XX irrumpen alteraciones en la enunciación del documental que suponen una renovación de los pactos de representación, ello hizo posible nuevas miradas del "yo", como la de Akerman. Surgen nuevas modalidades y formas de entender el cine de no ficción que Bill Nichols intentará abarcar en su concepto de "documental performativo", para paliar las carencias de su primer trabajo teórico. El subjetivismo se había implantado en el documental. Esta idea de lo subjetivo siempre se ha intentado descartar del documental por temor a derivar en una especie de falsificación que perjudicara el estatus factual del documental.

El "Cinema Vérité» es una primera reflexión en este sentido ya que por primera vez el cineasta encarna lo real, pero, sobre todo, está dotado de la escritura fílmica para expresar lo vivido. El "Direct Cinema» modificaba el espinoso término "verdad» por el más ajustado "directo", dado que no se trataba de reflejar la verdad, sino que la verdad era lo inmediato, lo directo. Este tipo de acercamiento documental minimizaba la intrusión del autor, captando la espontaneidad y viveza de los hechos cotidianos e involucrando a los participantes en el proceso, justificando la presencia de la cámara y permitiendo que la enunciación se desvelara en proceso catalizador de lo que surge en pantalla. Así pues, mientras el cine directo, aboga por una mínima intervención del director para permitir que la realidad se desarrollara tal y como es ante la cámara, el documental subjetivo no tendría problema en hacer evidente su intervención, legitimando incluso al cineasta para incitar los "momentos privilegiados» (Rouch en Nichols, 1997) en lugar de esperar pasivamente a que los hechos ocurran. De esta manera, independientemente de la modalidad de documental en el que el documentalista trabaje, siempre se altera la realidad de alguna forma, aunque sólo sea por la presencia de la cámara como ocurre en este cine directo. Stella Bruzzi (2006) explica precisamente cómo esa intervención en el que se implica el cineasta se ha dado incluso antes de la eclosión del documental subjetivo:

It is not just Robert Flaherty, the founding father of dramatic reconstruction, who incorporated performance into documentaries; in the work of filmmakers as diverse as Dziga Vertov, Georges Franju, Emile de Antonio, Chris Marker, Claude Lanzmann and Marcel Ophuls repeated use is made of performance, not a means of invalidating the 
documentary pursuit but of getting to the truth each filmmaker is searching for (Bruzzi, 2006, p. 153).

Entiende, por tanto, lo performativo como una extensión lógica de los intereses de la tradición más clásica del documental, ambas emparentadas en la búsqueda de la representación e interpretación de una realidad. Con los años, en un proceso de madurez y autoconciencia, el documental ha reparado en las limitaciones que presenta su afán por proporcionar conocimientos al espectador, lo que ha llevado a los cineastas de las últimas tres décadas a desvelar las fisuras de la no ficción sin pudor, consiguiendo con ello expandir, liberar y enriquecer el concepto de documental, y llevándole por trayectorias antes inexploradas en un ejercicio de extraordinaria creatividad. Y es que la autenticidad del documental residirá finalmente en ser una mirada organizadora de la vida y no en la fidelidad mecánica a lo real.

Resulta lógico que sea en este ambiente cuando eclosione, se generalice y se consolide definitivamente el documental íntimo, con obras que van desde el autorretrato hasta el diario personal o las cartas filmadas. Es en este último donde Akerman abunda en la subjetividad documental a través de la narración epistolar en primera persona, el encuentro con lo cotidiano, la reflexión sobre la alteridad materna -que al tiempo examina diversas cuestiones de carácter feminista-, la expresión de lo íntimo y lo privado o de su propia identidad como núcleo de sus trayectos narrativos: "Estoy desconectada de casi todo [...] casi no miro, casi no oigo. Medio ciega, medio sorda. Solo floto. A veces me hundo, pero no del todo [...] Me siento tan desconectada que no consigo tener una casa con pan, mantequilla, café, leche, papel higiénico...Cuando voy a comprar siento como si realizara un acto heroico. En resumen, no sé cómo vivir [...] Hay algo en mí que está roto. Mi relación con lo real, con lo cotidiano» (Akerman, 2006).

\section{CONCLUSIONES}

La investigación hasta aquí realizada plantea cuatro conclusiones, la primera de las cuales, tiene que ver con la subjetividad y como ésta se expone en las propuestas de cine documental íntimo, con absoluta franqueza, entendiéndose incluso como una seña de identidad en este tipo de piezas. Incluso tratando temas que afectan e implican al autor directamente en lo personal, se trata de una subjetividad documental representada. Si en los documentales más convencionales se busca la aspiración a lo objetivo con una diversificación de los puntos de vista, en el caso del documental autobiográfico el punto de vista es prácticamente único, el del autor, o al menos es el punto de vista que predomina. Tal es el caso de Akerman, donde la cámara expresa la mirada subjetiva de la directora-protagonista en todo momento, a través de su visión de Nueva York como excusa para el diálogo íntimo. Este enfoque, sin embargo, no atenúa ni merma su estatus como documental o ese valor de documento de lo real. En la mayoría de los casos siempre existe una visión global y final de la autora que impera en el conjunto del documental, y sobresale por encima de otros puntos de vista, opiniones y reflexiones que se ofrezcan y contrapongan. Por tanto, una propuesta de cine documental íntimo, autobiográfico, de autorretrato o de otra índole similar, no resulta descabellada ni supone una contradicción con respecto a la tradición documental, simplemente es una evolución en la que se es más consciente de sus posibilidades. 
En segundo lugar, este tipo de cine renuncia, en la mayoría de los casos, a abordar cuestiones de gran envergadura y amplitud, por otras de tipo más cotidiano y, en apariencia, intrascendentales. Siendo así, el cine documental íntimo se transfigura en representación de lo cotidiano. El entusiasmo con el que Akerman expresa esa parcela de lo personal, le sirve para derivar en interrogantes intangibles, donde hay cabida para la reflexión filosófica e intelectual y el ejercicio poético y experimental, pasando por temas como la muerte, la enfermedad, el paso del tiempo, la memoria, la familia, la felicidad...

En tercer lugar, la ficción y no ficción en el documental íntimo se suma a los rasgos anteriores como una tendencia común, donde se entremezclan sin pudor. Un recurso que desdibuja las fronteras entre lo que es documental y lo que no es. Lo interesante de esta tendencia, cada vez más generalizada en el documental contemporáneo, es cómo abre y posibilita nuevos caminos que anteriormente eran impensables. Si la no ficción no implica únicamente dejar un testimonio de lo real, no sólo se buscará ofrecer hechos e información, sino que necesitará además sumergirse más profundamente en sus temas y cuestiones. Difuminar esas fronteras entre la ficción y el documental, hasta hacerlas indistinguibles, no deja de ser otro recurso más para alcanzar ese objetivo, presente en todo documental, enriqueciendo el discurso y potenciando y actualizando sus procedimientos. Al final, en este tipo de documentales, la cuestión sobre qué parte de la obra es documento y cuál ficción pierde relevancia en aras de apreciar cómo ambos se enriquecen mutuamente. En este contexto, el trabajo de Chantal Akerman manifiesta su singularidad en el contexto del documental íntimo, al tiempo que forma parte del conjunto de propuestas que afianzan el documental contemporáneo en su marcha hacia lo subjetivo de los acontecimientos. La aportación de la cineasta pasa por elevar la voz femenina en un refinado ejercicio que desde la presencia ineludible del "yo", representa el conjunto de voces. Y ello es posible gracias a un elaborado proceso de empatía que se opera desde su singular escritura fílmica: planos largos en el tiempo, movimientos suaves en el espacio, personajes cotidianos en mundos ordinarios.

Por último, y como conclusión general, comprobamos cómo la necesidad de conceptualizar y delimitar las fronteras del trabajo documental se enfrenta al hecho de que, dentro del terreno de la reflexión teórica, siempre se aspirará a encajarlo como un ejercicio clausurado, cuando en la práctica es tremendamente rico y variado, de ahí la dificultad y quizá la ineficacia de querer establecer una tipología cerrada para el documental íntimo y autobiográfico. Ello se comprueba en su propio desarrollo a lo largo del tiempo: en su proceso de avance hacia una radicalización y generalización de la subjetividad, el documental se libera de ataduras autoimpuestas y demanda una mayor creatividad, donde no exista el prejuicio de mezclar recursos expresivos y heterogéneos abiertamente, redefiniendo de este modo, el concepto mismo de documental.

\section{Bibliografía}

Bellour, R. (2009). Entre imágenes. Foto, cine, video. Buenos Aires: Ediciones Colihue SRL. Bruzzi, S. (2006). New documentary: A Critical Introduction. London; N.Y.: Routledge. Cousins, M. (2005). Historia del cine. Barcelona: Blume.

Cuevas, E. (2005). Diálogos entre el documental y la vanguardia en clave autobiográfica. En J. Cerdán y C. Torreiro (eds.), Documental y Vanguardia (pp. 219-250). Madrid: Cátedra. 
Recuperado el 7 de enero de 2017: http://dadun.unav.edu/bitstream/10171/3380/1/Doc\%20 $\mathrm{AB} \% 20 \mathrm{y} \% 20$ vanguardia.pdf

Cuevas, E. (2008). Del cine doméstico al autobiográfico: caminos de ida y vuelta. En G. Martín. (ed.), Cineastas frente al espejo (pp. 101-120). Madrid: T\&B Ediciones

Lagos Labbé, P. (2011). Ecografías del "Yo»: Documental autobiográfico y estrategias de (auto) representación de la subjetividad. Revista Comunicación y Medios, 24, 66-80. Recuperado el 7 de enero de 2017: DIALNET, https://dialnet.unirioja.es/servlet/articulo?codigo=5242693

Lagos Labbé, P. (2012). Primera Persona Singular. Estrategias de (auto) representación para modular el "yo» en el cine de no ficción. Revista Comunicación y Medios, 26, 12-22. Recuperado el 7 de enero de 2017: DIALNET, https://dialnet.unirioja.es/descarga/articulo/5242941.pdf

Lane, J. (2002). The autobiographical documentary in America. Wisconsin: University of Wisconsin Press.

Lejeune, P. (1994). El pacto autobiográfico. Madrid: Megazul-Endymion.

Lejeune, P. (2008). Cine y Autobiografía, problemas de vocabulario. En G. Martín (ed.), Cineastas frente al espejo (pp. 13-26). Madrid: T\&B Ediciones.

Longfellow, B. (1989). Love Letters to the mother: the work of Chantal Akerman. Canadian Journal of Political and Social Theory, vol 13, 1-2, 73-90. Recuperado el 7 de enero de 2017: https://journals.uvic.ca/index.php/ctheory/article/view/14207

Marías, M. (2005). Viajera solitaria. En Chantal Akerman: Lprogramación del ciclo Chantal Akerman en la filmoteca española] (pp. 7-9). Madrid: Filmoteca Nacional

Nichols, B. (1997). La representación de la realidad: cuestiones y conceptos sobre el documental. Barcelona: Paidos Ibérica.

Ogea, P. (2005). Galería Elba Benítez. En Chantal Akerman: [programación del ciclo Chantal Akerman en la filmoteca española] (pp. 10-13). Madrid: Filmoteca Nacional

Otero, R. (2005). La identidad judía de Chantal Akerman en» aujourd-hui, dis-mois(1982). En I Congreso Internacional Sobre El Cine Europeo Contemporáneo (CICEC) (pp. 46). Barcelona: Universitat Pompeu Fabra. Recuperado el 7 de enero de 2017:

DIALNET, https://dialnet.unirioja.es/servlet/articulo?codigo=5394499

Palacio, M. (2005). El eslabón perdido: apuntes para una genealogía del cine documental contemporáneo. En J. Cerdán y C. Torreiro (eds.), Documental y Vanguardia (pp. 161-184). Madrid: Cátedra. 
